UDK 532.517.4

\author{
E.V. Kravets \\ Oles Honchar Dnipro National University
}

\title{
INFLUENCE OF TURBULENCE MODEL ON EXACTNESS CALCULATION OF WING AERODYNAMICS IN SUBSONIC STREAM
}

The analysis of some modern methods which provide the numerical simulation of the subsonic turbulent viscous flow with the complicated geometrical configuration bodies according to the "timeexactness" criterion is conducted. The three-dimensional simulation of viscous incompressible flowing around of wing with the profile of NACA-23012 by the finite elements method using six turbulence models is executed. The models used are the model of Spalart-Allmaras, the standard k- $\varepsilon$ model, Menter model of Shear Stress Transport, the models of Large Eddy Simulation and Detached Eddy Simulation, the model of Scale Adaptive Simulation. Some of these turbulence models features, advantages and disadvantages are mentioned. In the issue of numerical research the diagrams of drag, lift and wing torque coefficients versus the angle of attack in the range of $-8 \div 26$ degrees at the value of Reynolds number $4.4 \cdot 10^{5}$ are got. The compared of the expected wing aerodynamic parameters to the results of Central Aero- and Hydrodynamic Institute (TsAGI) experiment is executed. The table of the calculating error values between the wing lift (numerical calculation) and similar data of aerodynamic experiment at the critical angle of attack is put. For the considered class of three-dimensional problems of flow with the complicated geometrical configuration objects by the viscous incompressible flow the models of turbulence which provide the minimum of the calculation time and the maximum of the got results exactness are recommended. Such advisable models are the model of Spalart-Allmaras and k- $\omega$ Menter model of Shear Stress Transport.

Key words: incompressible flow of the viscous liquid, finite elements method, turbulence model, flow around the wing profile, boundary layer, three-dimensional simulating, drag, lift, torque, angle of attack.

Проведен анализ по критерию «время-точность» некоторых современных методов, обеспечивающих численное моделирование дозвукового турбулентного вязкого обтекания тел сложной геометрической конфигурации. Выполнено трехмерное моделирование обтекания крыла с профилем NACA-23012 вязкой несжимаемой жидкостью методом конечных элементов с применением шести моделей турбулентности: модели Спаларта-Аллмараса, стандартной k- $\varepsilon$ модели, модели сдвиговых напряжений Ментера, моделей крупных и отсоединенных вихрей, модели адаптивных масштабов. В перечисленных моделях турбулентности отмечены некоторые их особенности, преимущества и недостатки. В результате численного моделирования получены графические зависимости коэффициентов аэродинамического сопротивления, подъемной силы и момента вращения крыла от угла атаки в диапазоне $-8 \div 26$ градусов при значении числа Рейнольдса, равном $4.4 \cdot 10^{5}$. Выполнено сравнение рассчитанных аэродинамических характеристик крыла с результатами аэродинамического эксперимента Центрального аэрогидродинамического института (ЦАГИ). Приведена таблица погрешности отклонений коэффициента подъемной силы крыла (численный расчет) от аналогичных данных аэродинамического эксперимента при критическом угле атаки. Для рассмотренного класса трехмерных задач обтекания тел сложной геометрической конфигурации вязкой несжимаемой жидкостью рекомендованы модели турбулентности, обеспечивающие минимизацию времени проведения расчетов и наибольшую точность получаемых результатов: модель СпалартаАллмараса и модель сдвиговых напряжений k-ஸ SST Ментера.

Ключевые слова: несжимаемое течение вязкой жидкости, метод конечных элементов, модель турбулентности, обтекание профиля крыла, пограничный слой, трехмерное моделирование, аэродинамическое сопротивление, подъемная сила, момент вращения, угол атаки.

Проведено аналіз за критерісм «час-точність» деяких сучасних методів, що забезпечують чисельне моделювання дозвукового турбулентного в'язкого обтікання тіл складної геометричної конфігурації. Виконано тривимірне моделювання обтікання крила 3 профілем NACA-23012 в'язкою нестисливою рідиною методом скінченних елементів із застосуванням

(C) Kravets E.V., 2018 
шести моделей турбулентності: моделі Спаларта-Аллмараса, стандартної k-є моделі, моделі зсувних напружень Ментера, моделей великих та від'єднаних вихорів, моделі адаптивних масштабів. В перерахованих моделях турбулентності відзначено деякі їх особливості, переваги та недоліки. В результаті чисельного моделювання отримано графічні залежності коефіціснтів аеродинамічного опору, підйомної сили та моменту обертання крила від кута атаки в діапазоні $-8 \div 26$ градусів при значенні числа Рейнольдса, що дорівнюе $4.4 \cdot 10^{5}$. Виконано порівняння розрахованих аеродинамічних характеристик крила 3 результатами аеродинамічного експерименту Центрального аерогідродинамічного інституту (ЦАГІ). Наведено таблицю похибки відхилень коефіціснту підйомної сили крила (чисельний розрахунок) від аналогічних даних аеродинамічного експерименту при критичному куті атаки. Для розглянутого класу тривимірних задач обтікання тіл складної геометричної конфігурації в'язкою нестисливою рідиною рекомендовано моделі турбулентності, що забезпечують мінімізацію часу проведення розрахунків та найбільшу точність отриманих результатів: модель Спаларта-Аллмараса та модель зсувних напружень k- $\omega$ SST Ментера.

Ключові слова: нестислива течія в'язкої рідини, метод скінченних елементів, модель турбулентності, обтікання профілю крила, пограничний шар, тривимірне моделювання, аеродинамічний опір, підйомна сила, момент обертання, кут атаки.

Introduction. Turbulence (from lat. turbulentus - stormy, disorderly) or turbulent flow is a phenomenon consisting in the formation of numerous linear or nonlinear fractal (self-similar) waves in a liquid or gas with an increase of the velocity higher than some critical limit without the presence (and/or in a presence) of external, random, disturbing environment forces [16].

The first systematic researches of laminar and turbulent flows were executed by Osborn Reynolds [9], as a result of that Reynolds proposed a similarity law, later named after him.

In the last decades, in spite of rapid development of computer technique it was not succeeded to attain the reliable simulation of the real turbulent flows from chaotic nature and three-dimensional character of appearing vortices. As marked in [10] for a turbulent liquid are characteristic "shuttles of a velocity in all directions with the large number of freedom degrees". For the account of such process use the turbulence models, that carry semi-empiric character and based on average by Reynolds of Navier-Stokes equations (Reynolds Average Navier-Stokes - RANS). Thus, the calculation of moving individual vortices is substituted by the calculation of empiric values defining the averaged picture of turbulence distribution [2].

Presently at the simulating of turbulence all greater distribution is got the methods of direct numeral simulation (Direct Numerical Simulation - DNS), simulation of large vortices (Large Eddy Simulation - LES) [1], and also methods of simulation of the disconnected vortices (Detached-Eddy Simulation - DES) and simulation of adaptive scales (Scale Adaptive Simulation-SAS). However, at the decision three-dimensional problems of aerodynamics these methods require the considerable expenses of calculable resources [3, 12, 14]. Prognosis readiness of turbulence simulating is presented in Table 1 [11].

Formulation of the problem. In this paper, the possibilities of modern numerical simulation by the finite element method of subsonic flow around a wing with a NACA23012 profile by incompressible viscous liquid are analyzed. A comparative analysis of the wing integral characteristics (aerodynamic coefficients of drag, lift and torque) is performed depending on the angle of attack using six models of turbulence: Spalart-Allmaras $S A$ [12], Menter's shear stresses k- $\omega$ SST (Shear Stress Transport) 7], the standard k- $\varepsilon$ model of turbulence [6], the methods of modeling the adaptive scales $S A S$ [8], the disconnected vortices DES [13], large vortices LES [5]; as well as verification of the results of calculations by comparison with the data of the aerodynamic experiment [4]. 
Calculable resources and prospects of practical application

of different methods to the simulating of turbulence [11]

\begin{tabular}{|c|c|c|c|}
\hline Methods & $\begin{array}{c}\text { Necessary number } \\
\text { of net nodes }\end{array}$ & $\begin{array}{c}\text { Necessary number } \\
\text { of steps at times }\end{array}$ & Prognosis readiness ${ }^{1}$ \\
\hline 3D Steady RANS & $10^{7}$ & $10^{3}$ & 1985 \\
\hline 3D Unsteady RANS & $10^{7}$ & $10^{3,5}$ & 1995 \\
\hline DES & $10^{8}$ & $10^{4}$ & 2000 \\
\hline LES & $10^{11,5}$ & $10^{6,7}$ & 2045 \\
\hline DNS & $10^{16}$ & $10^{7,7}$ & $2080^{3}$ \\
\hline
\end{tabular}

${ }^{1}$ Prognosis readiness - calculation of one variant during twenty-four hours on most powerful computer from existent on the indicated period.

${ }^{2}$ It is LES with a near of wall RANS-simulating; in case of LES up to hard walls - expenses appear comparable with expenses DNS.

${ }^{3}$ On a computer with the productivity in 1 teraflop the calculation time is 5000 years (FLOPS - from the eng. - FLoating-point Operations Per Second - the off-system unit used for measuring of the computers productivity and showing, how many operations with a floating point per a second execute this computer system).

According to [4], the wing model had a rectangular shape in the plan with dimensions of $1.8 \mathrm{~m}$ in span and $0.3 \mathrm{~m}$ in the chord. The ends of the wing model were rounded according to the method adopted in TsAGI: the radius of the fillet was equal to half the thickness of the profile in the given section of the chord (Fig. 1).

The flow velocity was assumed to be $21.3 \mathrm{~m} / \mathrm{s}$, which corresponded to $\operatorname{Re}=4.4 \cdot 10^{5}$. The angle of attack varied within $\alpha=-8 \div 26$ degrees.

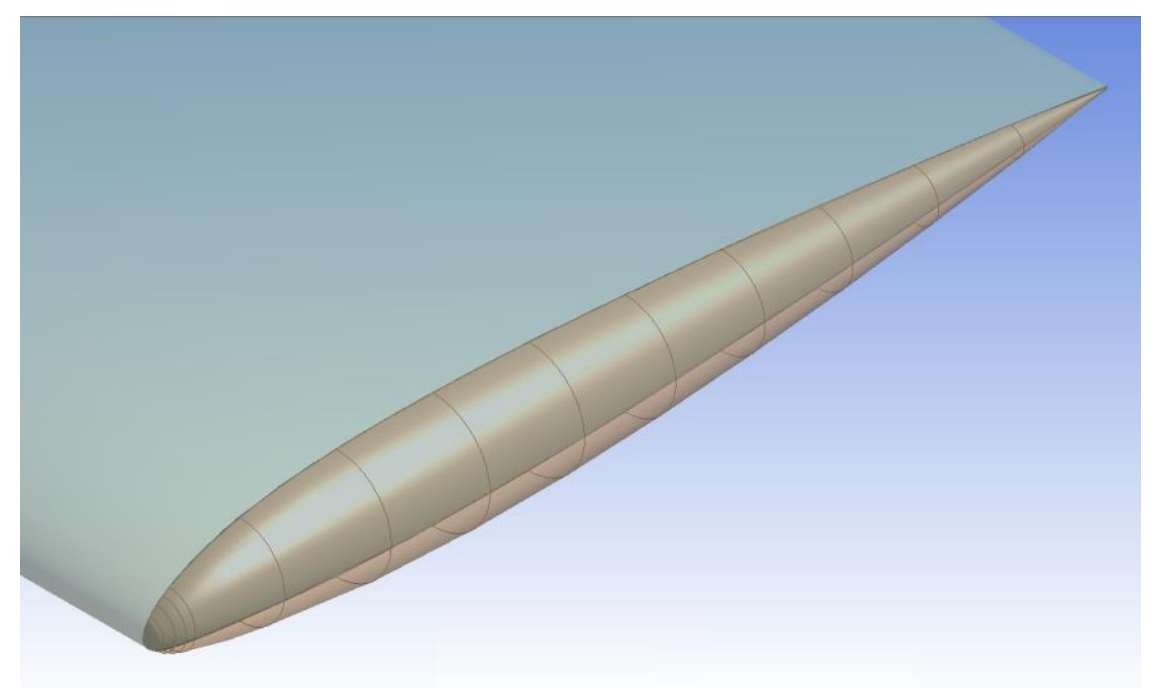

Fig. 1. Wing model with rounded end

Aerodynamic coefficients of drag, lift and torque were determined by formulas (1-3), respectively:

$$
C_{X}=\frac{X}{\frac{\rho V_{\infty}^{2}}{2} \cdot S_{P L}},
$$




$$
\begin{gathered}
C_{Y}=\frac{Y}{\frac{\rho V_{\infty}^{2}}{2} \cdot S_{P L}} . \\
m_{Z}=\frac{M}{\frac{\rho V_{\infty}^{2}}{2} \cdot S_{P L} \cdot L},
\end{gathered}
$$

where X - drag; Y - lift; M - torque; $C_{X}$ - coefficient of drag; $C_{Y}$ - coefficient of lift; $m_{Z}$ - coefficient of torque; $V_{\infty}$ - velocity at infinity; $\rho$ - density of air; $S_{P L}=S_{P L W I N G}+S_{P L \text { FILL }}-$ planed wing area without fillets $\left(S_{P L W I N G}\right)$ and with fillets $\left(S_{P L F I L L}\right) ; L$ - wingspan.

Results. Using the finite element method and six turbulence models, the aerodynamic coefficients of $\operatorname{drag}\left(C_{X}\right)$, lift $\left(C_{Y}\right)$ and the torque $\left(m_{Z}\right)$ of the wing with the NACA-23012 profile were obtained as a function of the angle of attack and compared with the results of the TsAGI aerodynamic experiment [4] (fig. 2).

Comparative analysis of turbulence models. The Spalart-Allmaras turbulence model $\boldsymbol{S A}$ was developed for the purpose of carrying out calculations in the space industry and is a relatively new one-parameter model containing one equation for turbulent viscosity transfer. The advantages of this model are the ease of implementation, as well as good agreement of the parameters under study in the boundary layer of the streamlined body with the results of the aerodynamic experiment. The coincidence of the calculated aerodynamic coefficients of drag, lift and torque with the experimental values is realized up to the angle of attack $\alpha=22^{0}$ (fig. $2, a$ ).

During the calculations, a significant dependence of the obtained aerodynamic characteristics on the degree of grinding of the calculated grid in the boundary layer of the streamlined wing was found. More accurate results, this turbulence model can also be obtained at low Reynolds numbers, which is its feature. It is noted in [15] that, due to insufficient testing of this model, it is not recommended to use it for flows that drastically change from a near-walled region to a free region with no tangential stresses, which is the case in problems with separation of the boundary layer.

The standard k- $\varepsilon$ turbulence model contains two equations for determining the transfer of the kinetic energy $\mathrm{k}$ and the dissipation rate $\varepsilon$. The coefficients in the equations are obtained by generalizing the experimental data, so the model is semi-empirical. In the derivation of the model equations, the assumption of negligible molecular viscosity in the flow was introduced, which indicates the applicability of the standard k- $\varepsilon$ turbulence model only for fully developed turbulent flows far from the solid walls.

The aerodynamic coefficients of the wing obtained using this model are shown in fig. $2, b$. It can be seen from the graph that in the subcritical region, compared with the experiment, the model is not workable: $\Delta \mathrm{C}_{\mathrm{X}}^{\mathrm{MAX}}=110 \% \quad\left(\alpha=11^{0}\right), \Delta \mathrm{C}_{\mathrm{Y}}^{\mathrm{MAX}}=17 \%$ $\left(\alpha=12^{0}\right), \Delta \mathrm{m}_{\mathrm{Z}}^{\mathrm{MAX}}=21 \%\left(\alpha=10^{0}\right)$. 

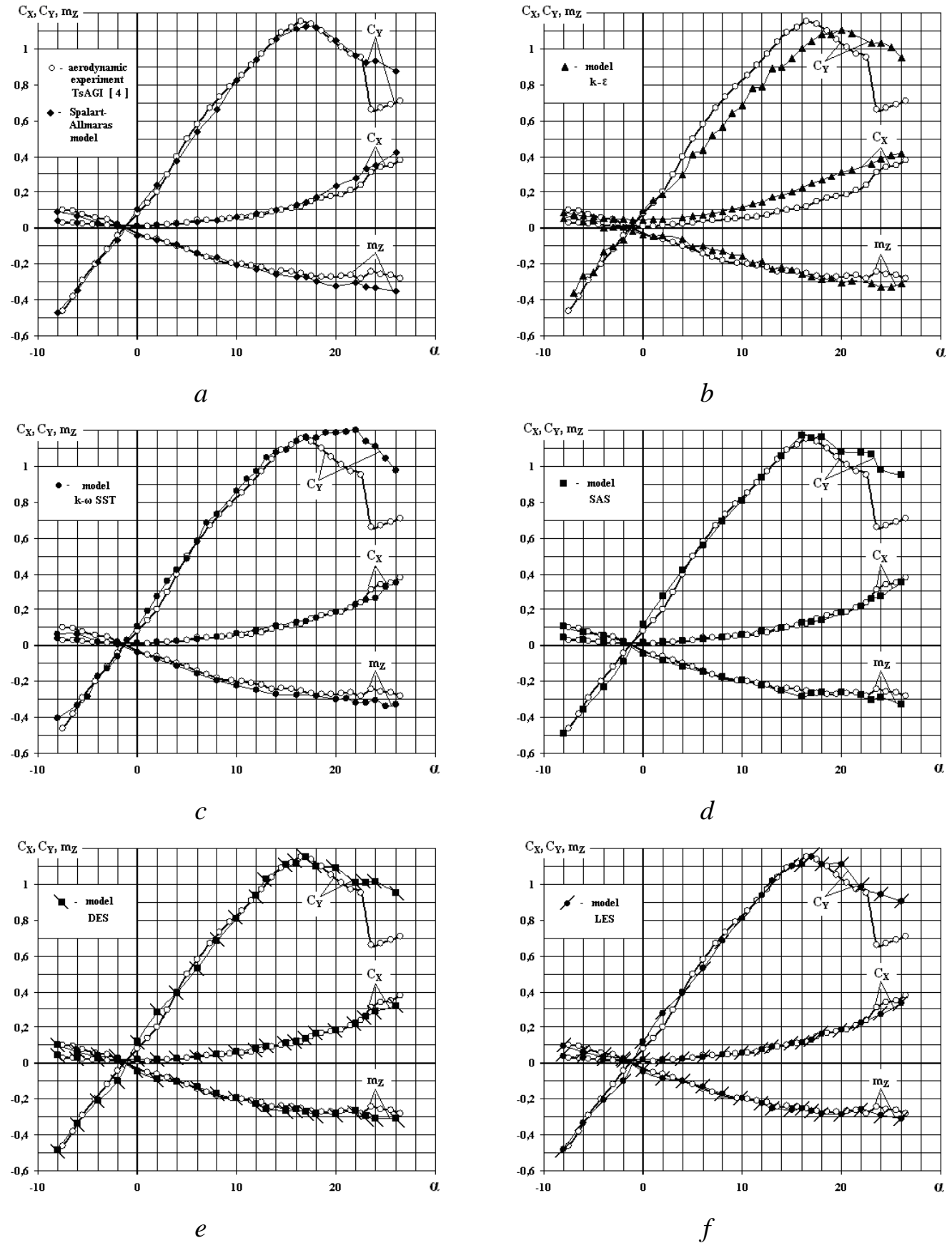

Fig. 2. Aerodynamic characteristics $C x, C y, m_{z}$ of profile NACA-23012; comparison of the TsAGI aerodynamic experiment [4] results with numerical calculations using turbulence models: $a$-Spalart-Allmaras; $b$-standard $\mathrm{k}-\varepsilon$; $c-\mathrm{k}-\omega \mathrm{SST}$ (Menter model); $d$-SAS; $e-\mathrm{DES} ; f-\mathrm{LES}$ 
The shear stress model k- $\omega S S T$ is a version of the k- $\omega$ model, which was created by Wilcox [14] for the calculation of wall flows with boundary layer separation at low Reynolds numbers. The k- $\omega S S T$ model developed by Menter combines the best sides of the k- $\omega$ and k- $\varepsilon$ models: the accuracy of calculating detached flows at low Reynolds numbers in near-wall regions (the advantage of the k- $\omega$ model), and also away from solid walls (advantage $\mathrm{k}-\varepsilon$ model). The results obtained using this model are shown in fig. 2, $c$ and have a higher accuracy than the results of the Spalart-Allmaras turbulence model when calculating external flows to the critical angle of attack.

The model of large vortices $\boldsymbol{L E S}$ is used to calculate turbulent flows with largescale vortex structures and is based on equations called "filtering" to exclude vortices that are smaller than the size of the grid cell. The basic idea of this model is the local averaging of the turbulent flow characteristics in bounded regions determined by the size of the filter. Due to the high requirements imposed by this model on computing resources, its practical applications are currently limited only to problems with a simple geometry of the computational domain.

The method of adaptive scales $\boldsymbol{S A S}$ is an improvement of RANS averaging for non-stationary flows. Like the $L E S$ method, the adaptive scaling method $S A S$ adapts to the structure of a non-stationary turbulent flow and allows localizing large vortices. Thus, in the stationary case, the SAS method is similar to averaging RANS, otherwise it is LES.

The method of disconnected vortices DES combines the Reynolds simulation of RANS with the LES large-scale vortex method. In this case, the Reynolds equations are realized in the regions near the walls with the formation of the boundary layer, and in the free flow with separation of the boundary layer and the dominance of large vortices, the $L E S$ technique is used. The accuracy of the DES method increases with the Reynolds number, so it is used mainly for high-speed external flows.

The aerodynamic coefficients of drag, lift and torque of the wing with the NACA23012 profile as a function of the attack angle for the turbulence models $S A S, D E S$ and $L E S$ are shown in fig. $2, d-f$, respectively. Comparison of the numerical results with aerodynamic experiment data allows us to state that for the DES and LES models at $\alpha \leq 17^{0}$ the deviation of the calculated aerodynamic coefficients of the wing from the experimental data was not detected.

The deviation of the lift coefficient of wing with NACA-23012 profile (numerical calculation) in comparison with the analogous data of the aerodynamic experiment [4] at $\alpha=17^{\circ}$

\begin{tabular}{|c|c|c|c|c|c|}
\hline \multirow{2}{*}{$\begin{array}{l}\text { Turbulence } \\
\text { model }\end{array}$} & \multirow{2}{*}{$\begin{array}{c}\text { Attack angle } \\
\alpha, \text { degree }\end{array}$} & \multicolumn{2}{|c|}{$C_{y}$} & \multirow{2}{*}{$\left|\Delta C_{y}\right|$} & \multirow{2}{*}{$\left|\Delta C_{y}\right|, \%$} \\
\hline & & experiment & $\begin{array}{l}\text { numerical } \\
\text { calculation }\end{array}$ & & \\
\hline SA & \multirow{6}{*}{17} & \multirow{6}{*}{1.15} & 1.1243 & 0.03 & 2.61 \\
\hline $\mathrm{k}-\varepsilon$ & & & 1.0418 & 0.11 & 9.57 \\
\hline k- $\omega$ SST & & & 1.1633 & 0.01 & 0.87 \\
\hline SAS & & & 1.1563 & 0.01 & 0.87 \\
\hline DES & & & 1.1518 & $\approx 0.00$ & $\approx 0.00$ \\
\hline LES & & & 1.1533 & $\approx 0.00$ & $\approx 0.00$ \\
\hline
\end{tabular}

In table 2 , for the lift coefficient $C_{Y}$, a deviation error is given when comparing the turbulence models used in comparison with the aerodynamic experiment for the critical attack angle $\alpha=17^{0}$. 
It can be seen from the table that the most accurate results in the boundary layer, corresponding to the minimum error, allow obtaining modern methods for simulating large $(L E S)$ and detached $(D E S)$ vortices, as well as hybrid non-stationary techniques $(S A S)$, which also take into account Reynolds averaging.

Conclusions. To carry out three-dimensional simulating of the external subsonic flow by viscous incompressible flows around bodies of a complex geometric configuration, the most optimal timing and accuracy of the obtained results can be adopted: the SpalartAllmaras model and the shear stress model k- $\omega$ SST Menter.

\section{Bibliographic references}

1. Гарбарук, А.В. Моделирование турбулентности в расчетах сложных течений: учебное пособие [Текст] / А.В. Гарбарук, М.Х. Стрелец, М.Л. Шур. - СПб.: Изд-во Политехн. Ун-та, 2012. $-88 \mathrm{c}$.

2. Кривцов, А.В. Изучение влияния качества сетки и моделей турбулентности на результаты CFD-расчета в ANSYS Fluent. Электрон. метод. указания к лаб. работам [Текст] / А.В. Кривцов, Л.С. Шаблий. - Самар. гос. аэрокосм. ун-т им. С.П. Королева. - Самара, 2013. - 47 с.

3. Приходько, А. А. Компьютерные технологии в аэрогидродинамике и тепломассообмене [Текст] / А.А. Приходько. - К.: Наук. думка, 2003. - 380 с.

4. Радченко, П.И. Круговая обдувка профиля NACA 23012 в аэродинамической трубе Т-103Н ЦАГИ [Текст] / П.И. Радченко. - Технич. отчеты ЦАГИ им. проф. Н.Е. Жуковского. - 1959. - Вып. 161. - 24 с.

5. Kim, S.-E. Large eddy simulation using unstructured meshes and dynamic subgrid-scale turbulence models [Text] / S.-E. Kim // 34 3 Fluid Dynamics Conference and Exhibit American Institute of Aeronautics and Astronautics. Technical Report AIAA-2004-2548. - 2004. - 35 p.

6. Launder, B.E. Lectures in Mathematical Models of Turbulence [Text] / B.E. Launder, D.B. Spalding. - Academic Press. - London, England, 1972. - 169 p.

7. Menter, F.R. Two-Equation Eddy-Viscosity Turbulence Models for Engineering Applications [Text] / F.R. Menter // AIAA Journal. - 1994. - 32 (8). - P. 1598-1605.

8. Menter, F. The Scale-Adaptive Simulation Method for Unsteady Turbulent Flow Prediction. Part 1: Theory ans Model Description [Text] / F. Menter, Y.Egorov // Journal Flow Turbulence and Combustion. - 2010. - Vol. 85. - P. 113-138.

9. Reynolds, O. On the experimental investigation of the circumstances which determine whether the motion of water shall be direct or sinuous, and the law or resistance in parallel channels [Text] / O. Reynolds //Phill. Trans. Roy. Soc. - 1883. - № 174. - P. 935-982.

10.Saad, T. Turbulence modeling for beginners /T. Saad // University of Tennessee space institute - Access mode:

http: www.cfd-online.com/W/images/3/31/ Turbulence_Modeling_For_Beginners.pdf.

11.Spalart, P.R. Strategies for turbulence modeling and simulations [Text] / P.R. Spalart //Int. J. Heat Fluid Flow. - 2000. - Vol. 21. - P. 252-263.

12.Spalart, P. A one-equation turbulence model for aerodynamic flows [Text] / P. Spalart, S. Allmaras //American Institute of Aeronautics and Astronautics. Technical Report AIAA-920439. - 1992. - $17 \mathrm{p}$.

13.Spalart, P. A new version of detached eddy simulation, resistant to ambiguous grid densyities [Text] /P. Spalart, S. Deck, M. Shur, K. Squires, M. Strelets, A. Travin // Theoretical and Computational Fluid Dynamics. - 2006. - Vol. 20. - P. 181-195.

14.Wilcox, D.C. Turbulence Modeling for CFD [Text] / D.C. Wilcox. - DCW Industries, Inc. La Canada, California, 1998. - $540 \mathrm{p}$.

15.[Electronic resourse] - Access mode: http://cadsolutions.narod.ru/Cfd/pages/fluentdoc/ userguid/p1/p1.html - Title from the screen.

16.[Electronic resourse] - Access mode: https://ru.wikipedia.org/wiki/Турбулентность Title from the screen.

Надійшла до редколегії 11.03.18 